\title{
PROGRESS IN ULTRA-DEFORMABLE STAINLESS STEELS FOR MEDICAL TOOL APPLICATION
}

\author{
L. A. Maltseva ${ }^{1}$, S. Yu. Mitropolskaya ${ }^{1,2 *}$, A. V. Levina ${ }^{1}$ \\ ${ }^{1}$ Yeltsin UrFU. Institute of Materials and Metallurgy, 620002, 28 Mira st., Ekaterinburg, Russian Federation \\ ${ }^{2}$ Institute of Engineering Science, Ural Branch of the Russian Academy of Sciences, 34 Komsomolskaya st., \\ Ekaterinburg, Russian Federation
}
*Corresponding author. E-mail: mitr@imach.uran.ru; address fir correspondence: ul. Komsomolskaya, 34, 620049, Ekaterinburg, Russian Federation. Tel.: +7 (343) 375-35-70; fax: +7 (343) 374-53-30

This paper provides a survey of current trends in stainless steel design with the emphasis on strength mechanisms available for further progress. The paper is focused on deformable austenite and duplex wire steels suitable for intensive plastic strain. The advantages of a newly developed TRIP-steel of Fe-Cr-Ni-Co-Al-Ti composition over conventional stainless steels are discussed in terms of feasibility for large-scale production of tiny cross section medical core tools. High strength and superior formability of the steel makes it possible to avoid costly annealing treatment as a part of the cold deep-drawing technology. Saturation magnetization and coercivity measurements reveal the structural changes in course of deformation and thermal processing.

Keywords: stainless steels, medical core tools, deep drawing, TRIP-effect, magnetic measurements.

\section{References}

1. Shlyamnev A.P., Svistunova T.V., Lapshina O.B. Korrozionnostoykie, zharostoykie $i$ vysokoprochnye stali $i$ splavy: spravochnik [Corrosion-resistant, heat-resistant and high strength steels and alloys]. Moscow, Intermet Engineering Publ., 2000. 232 p. (In Russian).

2. Gorynin I.V., Malyshevsky V.A., Rybin V.V. Vysokoprochnye svarivaemye korpusnye stali dlya provodnogo korablestroeniya: vchera, segodnya, zavtra. $V$ knige: Rol rossiyskoy nauki $v$ sozdanii otechestvennogo podvodnogo flota [High strength weldable hull steels for submarines. In book The Role of the Russian Science in creating the domestic submarine fleet]. Moscow, Nauka Publ., 2008. 288 p. (In Russian).

3. Gavriljuk V.G., Berns H. High Nitrogen Steels. Berlin, Springer Verlag Publ., 1999. 378 p.

4. Sokol I.Ya., Struktura i korroziya metallov i splavov: atlas: spravochnik [Microstructure and corrosion behavior of metals and steels] (Ed. by E. A. Ulyanin). Moscow, Metallurgia Publ., 1989. 399 p. (In Russian).

5. Davison M., Redmond J.D. Practical guide to using duplex stainless steels. Materials Performance, 1990, vol. 29, pp. 57-62.

6. Marshall P. Austenitic Stainless Steels: Microstructure and Mechanical Properties. London, Elsevier Publ., 1984. ISBN: 0-85334-277-6.

7. Berns H., Gavriljuk V.G., Riedner S. High interstitial stainless austenitic steels. Berlin, Springer Verlag Publ., 2013. 167 p.

8. $\quad$ Sinha K. Ferrous Physical Metallurgy. Berlin, Butterworths Publ., 1989. 335 p.

9. Desestret A., Charles J. Eds: Baroux B., Beranger G. The duplex stainless steels. In Stainless steels. P. Lacombe. Les Ulis, France, Les editions de physique Publ., 1993, pp. 612-658.

10. Bernshtein M. L. Struktura deformirovannykh metallov [Microstructure of strained metals]. Moscow, Metallurgia Publ., 1977. 431 p. (In Russian).

11. Filippov M.A., Litvinov V.S., Nemirovsky Yu.R. Stali s metastabilnym austenitom [Metastable austenitic steels]. Moscow, Metallurgia Publ., 1988. 255 p. (In Russian).

12. Maltseva L.A., Ozerets N.N., Rossina N.G. Corrosion resistance of high strength Al-alloyed steels for medical tools application. Materialovedenie, 2009, no. 6, pp. 11-16. (In Russian). 
13. Goldshtein M.I., Litvinov V.S., Bronfin B.M. Metallofizika vysokoprochnykh splavov [Metal physics of high strength alloys]. Moscow, Metallurgia Publ., 1986. 312 p. (In Russian).

14. Maltseva L.A. Structure and strength of corrosion-resistant steel for medical application after thermo-mechanical. Deformatsiya i razrushenie materialov, 2010, no. 1, pp. 1-8. (In Russian). 


\title{
РАЗВИТИЕ ВЫСОКОТЕХНОЛОГИЧНЫХ КОРРОЗИОННОСТОЙКИХ СТАЛЕЙ ДЛЯ МЕДИЦИНСКОГО ИНСТРУМЕНТА
}

\author{
Л. А. Мальцева ${ }^{1}$, С. Ю. Митропольская ${ }^{1,2 *}$, А. В. Левина ${ }^{1}$ \\ ${ }^{I}$ ФГАОУ ВПО «УрФУ имени первого Президента России Б.Н.Ельиина.» Институт материаловедения \\ и металлургии, ул. Мира, 28, Екатеринбург, Российская Федерачия, 620002 \\ 2 Федеральное государственное бюджетное учреждение науки Институт машиноведения Уральского отделе- \\ ния Российской академии наук, ул. Комсомольская, 34, Екатеринбург, Российская Федерация, 620049 \\ *Ответственный автор. Электронная почта: mitr@imach.uran.ru; адрес для переписки: ул. Комсомольская, 34, \\ Екатеринбург, Российская Федерация. Телефон: +7 (343) 375-35-70; факс: +7 (343) 374-53-30
}

В статье дан обзор современных научных подходов к разработке коррозионностойких сталей, обозначены наиболее эффективные механизмы упрочнения таких материалов и пути их реализации. Основное внимание уделено сталям аустенитно-ферритного и аустенитного классов, предназначенным для производства проволоки за счет интенсивной пластической деформации. Обосновано преимущество вновь разработанных коррозионностойких композиций системы Fe-Cr-Ni-Co-Al-Ti для стержневого медицинского инструмента тонких и тончайших сечений, которые обладают хорошей пластичностью и технологичностью и не нуждаются в промежуточном отжиге по маршруту волочения. Показано, что измерения намагниченности насыщения и коэрцитивной силы позволяют проводить мониторинг структурных и фазовых превращений в материале при деформационно-термической обработке.

Ключевые слова: коррозионностойкие стали, стержневой медицинский инструмент, волочение с высокой степенью обжатия, TRIP-эффект, магнитные свойства.

\section{1. Введение}

Интерес к коррозионностойким сталям с каждым годом усиливается: разрабатываются новые химические составы, совершенствуются приемы термической и деформационной обработки, расширяются области применения. При этом экономические интересы потребителей во всем мире диктуют необходимость снижения содержания дефицитных и дорогостоящих легирующих элементов в составе этих материалов, а также оптимизации самого технологического процесса производства готовой продукции. Поиск оптимального легирования в сочетании со специализированной термомеханической обработкой - одно из основных направлений в металловедении сталей с метастабильным аустенитом. Особого внимания в этой связи требует производство стержневого медицинского инструмента тонких и тончайших сечений, для которого необходимо сочетание высокой прочности и коррозионной стойкости. Массовое производство такого инструмента, в частности, игл, включает в себя многопроходную холодную пластическую деформацию волочением и (или) плющением. Однако не все стали обладают хорошей пластичностью и технологичностью. До настоящего времени основной промышленной маркой стали для производства коррозионностойкой холоднотянутой проволоки является метастабильная аустенитная сталь $12 \mathrm{X} 18 \mathrm{H} 10 \mathrm{~T}$, которая имеет недостаточную пластичность и технологичность, невысокий уровень прочностных свойств даже в деформированном состоянии.

Цель настоящей работы - обосновать преимущества и перспективы применения коррозионностойких композиций системы Fe-Cr-Ni-Co-Al-Ti для изделий тонких и тончайших сечений вместо обычных хромоникелевых аустенитных сталей. 


\section{2. Основные классы и принципы легирования аустенитных коррозионностойких сталей}

Коррозионностойкие стали обладают стойкостью против электрохимической и химической коррозии в различных агрессивных средах (во влажной атмосфере, в морской воде, в растворах щелочей и кислот, в расплавах металлов). Их разделяют на классы в зависимости от структуры, которая в них образуется после высокотемпературного нагрева и охлаждения на воздухе: мартенситный, мартенситно-ферритный, ферритный, аустенитно-ферритный, аустенитный.

Наибольшее распространение получили аустенитные коррозионностойкие стали [1], основным преимуществом которых являются высокие служебные характеристики (прочность, пластичность, коррозионная стойкость в большинстве рабочих сред) и хорошая технологичность (деформируемость, свариваемость). Современная классификация коррозионностойких аустенитных сталей включает в себя пять основных групп.

1) Обычные аустенитные коррозионностойкие стали (Conventional austenitics), содержание углерода в которых может достигать $0,15 \ldots 0,25$ вес. \%. Углерод обеспечивает твердорастворное упрочнение аустенита, однако делает их склонными к зернограничной коррозии за счет выделения карбидов типа $\mathrm{M}_{23} \mathrm{C}_{6}$ и обеднения по хрому границ зерен. Поскольку выделение карбидов $\mathrm{M}_{23} \mathrm{C}_{6}$ происходит в интервале температур от 425 до $900{ }^{\circ} \mathrm{C}$, стали этого типа подвергают отжигу при более высоких температурах (обычно около 1050 $\ldots 1095^{\circ} \mathrm{C}$ ) для растворения карбидов и перевода хрома в твердый раствор с последующим быстрым охлаждением в воде, чтобы не допустить повторного выделения карбидов. Предел текучести таких сталей в отожженном состоянии невысок и составляет 200...250 МПа.

2) Стабилизированные аустенитные стали (Stabilized austenitic alloys), содержащие регламентированное количество титана, ниобия, тантала или колумбия, что приводит к выделению дисперсных карбидов типа $\mathrm{TiC}$ и $\mathrm{NbC}$ внутри зерна, но не допускает образования карбидов хрома типа $\mathrm{M}_{23} \mathrm{C}_{6}$ по границам зерен. Однако такие стали требуют дополнительной термообработки для снятия напряжений, для повышения технологической пластичности и вязкости. В отличие от обычных аустенитных сталей, стабилизированные стали можно охлаждать после отжига не в воде, а просто на воздухе.

3) Низкоуглеродистые марки коррозионностойких аустенитных сталей (Lowcarbon austenitics) по склонности к зернограничной коррозии занимают промежуточное положение между обычными и стабилизированными сталями. Содержание углерода в таких марках сталей не превышает 0,03 вес. \% и не способствует образованию зернограничных карбидов хрома. Стали этого типа в отожженном состоянии обладают очень низкой магнитной проницаемостью (1,02 при 0,02 Тл), однако под действием холодной деформации в них может образоваться низкоуглеродистый мартенсит, который обладает ферромагнитными свойствами. Определенную опасность представляет собой длительная эксплуатация низкоуглеродистых сталей при повышенных температурах: в интервале температур $540 \ldots 760{ }^{\circ} \mathrm{C}-$ в связи с возможным образованием карбидов, а в интервале температур $650 \ldots 870{ }^{\circ} \mathrm{C}-$ в связи с образованием б-фазы.

4) Азотистые коррозионностойкие аустенитные стали (High-nitrogen austenitic stainless steels) содержат обычно до 0,2 вес. \% азота, но известны марки с содержанием азота до 0,9 вес. \%, их называют супераустенитными. Уровень прочности этих сталей прямо пропорционален содержанию в них азота. Обычно предел текучести азотистых коррозионностойких сталей даже в отожженном состоянии превышает 400 МПа. Благоприятное влияние азота на структуру и свойства обусловлено, в том числе:

а) меньшим размером атомного радиуса азота, что способствует повышению его растворимости в $\gamma$ - и $\alpha$-железе по сравнению с углеродом;

б) более гомогенным распределением атомов замещения в твердых растворах железа, тогда как углерод инициирует кластерообразование; 
в) снижением энергии дефекта упаковки в кристаллической решетке железа, увеличением степени расщепления дислокаций, что способствует деформационному упрочнению, тогда как углерод действует наоборот;

г) существенно меньшими размерами нитридов, чем карбидов, что обусловливает их больший вклад в упрочнение [2,3].

Азотистые стали считаются устойчивыми против образования $\alpha^{\prime}$-мартенсита деформации и не нуждаются в отжиге для снижения магнитной проницаемости, которая не превышает значения 1,02 даже после значительной пластической деформации.

5) Высоколегированные аустенитные стали (Highly alloyed austenitic stainless steels) содержат значительное количество молибдена в количество до 4,0 вес. \% для обеспечения коррозионной стойкости в хлоридсодержащих средах, а также медь для придания кислотостойкости. Для таких сталей необходим отжиг в узком интервале температур $\left(1120 \ldots 1150{ }^{\circ} \mathrm{C}\right)$, чтобы избежать образования как $\sigma$-фазы, так и $\delta$-феррита.

В отдельные группы выделяют аустенитно-ферритные (дуплексные) стали и дисперсионно-упрочняемые коррозионностойкие стали.

Aустенитно-ферритные стали (Duplex stainless steels) могут содержать примерно равное количество аустенита и феррита, но могут иметь в качестве матричной фазы аустенит или феррит. По сравнению с аустенитными аустенитно-ферритные стали обладают повышенной прочностью, что особенно важно для низкоуглеродистых композиций [4]: прочностные характеристики сталей, содержащих от 40 до $60 \% \delta$-феррита, как правило, в два раза превосходят характеристики обычных аустенитных коррозионностойких сталей. Считается, что аустенитно-ферритные стали обладают повышенной стойкостью против межкристаллитной коррозии и коррозионного растрескивания в хлорсодержащих и щелочных средах [5].

Дисперсионно-упрочняемые коррозионностойкие стали (Precipitation-Hardening stainless steels) позволяют получать уникальную комбинацию высокой коррозионной стойкости с высокими прочностными характеристиками. Практически все дисперсионно-упрочняемые коррозионностойкие стали являются низкоуглеродистыми и содержат не более 0,1 \% С. Состав подбирается таким образом, чтобы обеспечить метастабильность аустенита в процессе

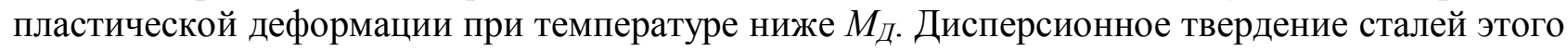
класса реализуется за счет выделения дисперсных частиц различных фаз в зависимости от особенностей легирования [6]:

a) $\gamma^{\prime}$-фазы на основе интерметаллидов $(\mathrm{Fe}, \mathrm{Ni})_{3} \mathrm{M}$, где $\mathrm{M}=\mathrm{Al}, \mathrm{Ti}, \mathrm{Nb}$ или $\mathrm{Mo}$;

б) $\beta$-фазы на основе интерметаллида (Fe, $\mathrm{Ni}) \mathrm{Al}$;

в) нитридов хрома типа $\mathrm{Cr}_{2} \mathrm{~N}$ и $\mathrm{CrN}$.

Дисперсионно-упрочняемые коррозионностойкие стали обладают, как правило, высокой технологической пластичностью и вязкостью, а после холодной деформации и заключительного старения в интервале температур $455 \ldots 565{ }^{\circ} \mathrm{C}$ приобретают предел текучести порядка 1600 МПа. Такие стали могут содержать $\delta$-феррит в количестве до $20 \%$, который практически не упрочняется при термообработке. Температура длительной эксплуатации таких сталей, как правило, не превышает $400{ }^{\circ} \mathrm{C}$, чтобы не допустить перестаривания.

На основании анализа многочисленных опубликованных данных [1-7] современные подходы к разработке химических композиций аустенитных коррозионностойких сталей можно обобщить следующим образом.

Хром в количестве не менее 12 вес. \% необходим для придания стали собственно коррозионной стойкости за счет создания на ее поверхности тонкого защитного слоя.

Никель является вторым по значимости легирующим элементом в сталях этого класса, поскольку расширяет область существования аустенита.

Марганец, являясь аустенитообразующим элементом, позволяет частично замещать дорогостоящий никель и повышает растворимость азота в аустените. 
Кобальт действует подобно марганцу и эффективно снижает энергию дефекта упаковки, способствуя протеканию деформационного $\gamma \rightarrow \varepsilon$ превращения, тем самым обеспечивая технологическую пластичность при холодной деформации [8].

Aзот стабилизирует аустенит и позволяет уменьшить количество никеля в композиции. При этом азот эффективно упрочняет твердый раствор, сохраняя вязкость разрушения на достаточно хорошем уровне.

Углерод также обеспечивает твердорастворное упрочнение аустенита, но выделение зернограничных карбидов типа $\mathrm{M}_{23} \mathrm{C}_{6}$ обедняет по хрому твердый раствор и способствует коррозии.

Молибден усиливает способность хромоникелевых сталей к самопассивации, существенно повышает стойкость против питтинговой коррозии и ножевой коррозии в хлоридсодержащих средах. Считается, что стойкость аустенитных сталей против питтинговой коррозии (СПК) напрямую определяется содержанием молибдена, хрома и азота и хорошо описывается формулой [9]:

$$
\mathrm{C \Pi К}=\% \mathrm{Cr}+3,3 \% \mathrm{Mo}+(16 \text { или } 30) \% \mathrm{~N},
$$

где количество легирующих элементов выражено через весовые проценты. Коэффициент для углерода в аустенитных сталях составляет 30, а в аустенито-ферритных - 16.

Алюминий и кремний повышают сопротивление окислению. Кроме того, алюминий входит в состав интеметаллидов типа (Fe, $\mathrm{Ni}) \mathrm{Al}$ и $(\mathrm{Fe}, \mathrm{Ni})_{3}(\mathrm{Al}, \mathrm{Ti})$, которые обеспечивают дисперсионное твердение. Являясь сильным ферритообразующим элементом, алюминий позволяет получать стали аустенитно-ферритного класса с различным соотношением аустенита и $\delta$-феррита.

Титан, ниобий, тантал или колумбий являются сильными карбидо- и карбонитридообразующими элементами, образуют дисперсные и стабильные равномерно распределенные карбиды, препятствуя тем самым образованию крайне нежелательных зернограничных карбидов типа $\mathrm{M}_{23} \mathrm{C}_{6}$.

Серу и селен добавляют в небольших количествах, если необходимо обеспечить обрабатываемость материала на станках.

Механизмы деформационного упрочнения метастабильных аустенитных сталей в интервале температур $M_{H}-M_{д}$ неоднократно обсуждались в литературе (наиболее подробно - в работах В. Д. Садовского, А. П. Гуляева, И. Н. Богачева) и определяются следующими основными факторами:

1) деформационным упрочнением аустенита, при этом деформационное упрочнение аустенита обусловлено повышением общей плотности дислокаций, изменению характера из распределения, измельчением блоков мозаичной структуры и возникновением барьеров Ломера-Коттрелла, а при низких значениях ЭДУ - дополнительно деформационным двойникованием и образованием дефектов упаковки [10];

2) количеством, распределением и прочностью образующихся при деформащии $\varepsilon$-мартенсита и $\alpha^{\prime}$-мартенсита. Дополнительное упрочнение от образования мартенсита деформации обусловлено как собственно более высокой твердостью мартенсита, так и созданием в зернах аустенита прочного каркаса из пластин мартенсита, препятствующих сдвиговым процессам в аустените. Твердость мартенсита деформации существенно выше, чем твердость мартенсита охлаждения, а охрупчивающее действие кристаллов мартенсита деформации выражено слабее, чем мартенсита охлаждения [11].

3) наклепом кристаллов мартенсита деформащии - за счет увеличения в них плотности дислокаций и деформационного двойникования.

С учетом того, что коррозионностойкие стали для стержневого медицинского инструмента должны обладать превосходной технологической пластичностью при холодной деформации волочением или плющением, а после заключительной обработки - высокой проч- 
ностью в сочетании с высокой коррозионной стойкостью, для их разработки целесообразно привлечь следующие металлофизические приемы:

1) свести к возможному минимуму содержание углерода и азота;

2) обеспечить получение аустенитной или аустенито-ферритной структуры;

3) за счет особенностей легирования и предварительной термической обработки управлять термодинамической и деформационной стабильностью аустенита с тем, чтобы обеспечить оптимальную степень реализации TRIP-эффекта в ходе холодной пластической деформации при сохранении высокой технологической пластичности (TRIP - Transformation Induced Plasticity - пластичность, наведенная превращением);

4) добиться дополнительного упрочнения материала на готовом размере за счет дисперсионного твердения.

\section{3. Оптимизация химического состава и деформационно-термическая обработка сталей системы Fe-Cr-Ni-Co-Al-Ti для стержневого медицинского инструмента}

На основании проведенных комплексных исследований на кафедре металловедения Уральского федерального университета были разработаны новые хромо-никелевые стали, дополнительно легированные $\mathrm{Co}$, Mo, Ti и $\mathrm{Al}$, предназначенные для изготовления высокопрочных проволоки и ленты тонких и тончайших сечений. По коррозионной стойкости они значительно превосходят обычную нержавейку как в закаленном состоянии, так и после деформации и старения [12]. Для исследования были выбраны три композиции, выплавленные на одной системе легирования:

- сталь аустенитного класса с повышенным содержанием кобальта (состав 4);

- сталь аустенитного класса с пониженным содержанием кобальта (состав 5);

- сталь аустенитно-ферритного класса с повышенным содержанием кобальта и алюминия (состав 6).

Химический состав этих сталей приведен в табл. 1, а фазовый состав - в табл. 2.

Таблица 1 - Химический состав исследованных сталей системы легирования 03Х14H11К5М2ЮТ

\begin{tabular}{|c|c|c|c|c|c|c|c|c|c|}
\hline \multirow{2}{*}{$\begin{array}{c}\text { Марка стали, } \\
\text { условный номер } \\
\text { химического состава }\end{array}$} & \multicolumn{9}{|c|}{ Содержание элементов, масс. \% } \\
\hline & $\mathrm{C}$ & $\mathrm{Si}$ & $\mathrm{Mn}$ & $\mathrm{Cr}$ & $\mathrm{Ni}$ & Mo & $\mathrm{Co}$ & $\mathrm{Ti}$ & $\mathrm{Al}$ \\
\hline $\begin{array}{c}\text { 03Х14Н11К5М2ЮТ, } \\
\text { состав } 4\end{array}$ & $\leq 0,03$ & 0,21 & 0,19 & 14,5 & 11,15 & 2,5 & 5,1 & 0,30 & 0,80 \\
\hline $\begin{array}{c}\text { 03Х14Н11КМ2ЮТ, } \\
\text { состав } 5\end{array}$ & $\leq 0,03$ & 0,30 & 0,08 & 14,7 & 10,52 & 2,7 & 0,7 & 0,36 & 0,98 \\
\hline $\begin{array}{c}\text { 03Х14Н10К5М2Ю2Т, } \\
\text { состав } 6\end{array}$ & $\leq 0,03$ & 0,20 & 0,07 & 14,3 & 10,40 & 2,6 & 5,1 & 0,80 & 2,00 \\
\hline
\end{tabular}

*Содержание $\mathrm{S}$ и $\mathrm{P}$ не более $0,025 \%$.

Таблица 2 - Фазовый состав сталей системы легирования 03Х14Н11К5М2ЮТ в закаленном состоянии

\begin{tabular}{|c|c|c|c|c|}
\hline \multirow{2}{*}{$\begin{array}{c}\text { Химический } \\
\text { состав }\end{array}$} & \multicolumn{2}{|c|}{ Фазовый состав, \% } & \multicolumn{2}{|c|}{$\mathrm{HV}_{50}$} \\
\cline { 2 - 5 } & ОЦК & ГЦК & ОЦК & ГЦК \\
\hline 4 & - & $\sim 100$ & - & 210 \\
\hline 5 & 10 & 90 & - & $\sim 210$ \\
\hline 6 & 50 & 50 & 505 & 190 \\
\hline
\end{tabular}


Все выплавленные композиции являются практически безуглеродистыми, содержание углерода в них не превышает $0,03 \%$. Варьирование содержания кобальта $(0,7 \ldots 5,1$ вес. \%) и алюминия $(0,8 \ldots 2,0$ вес. \%) позволило получить различное количество $\delta$-феррита в закаленном состоянии, при этом структурные классы выплавленных сталей меняются в последовательности: аустенитный (состав 4) $\rightarrow$ аустенитный, содержащий до $10 \% \delta$-феррита (состав 5) $\rightarrow$ аустенитно-ферритный (состав 6). Легирование кобальтом в количестве $~ 5,0$ вес. \% приводит к подавлению образования $\delta$-феррита (состав 4), а алюминий как сильный ферритообразующий элемент дает обратный эффект: дополнительное легирование алюминием в количестве 2,0 вес. \% позволяет получить дуплексную $\gamma+\delta$ структуру (состав 6 ).

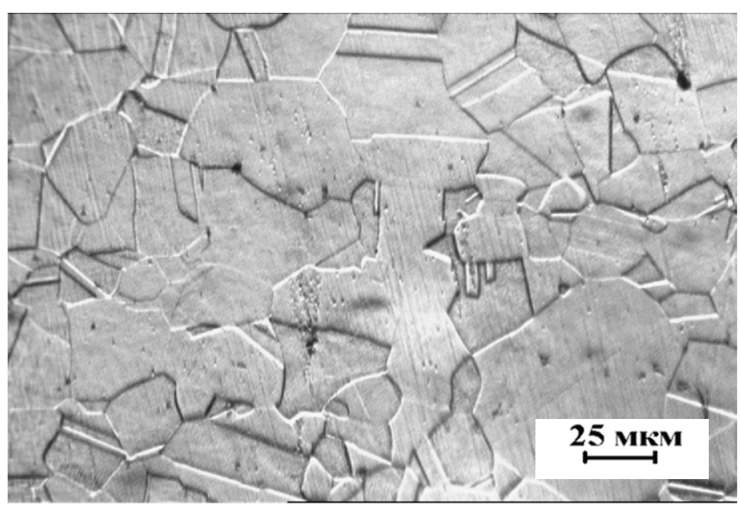

$a$

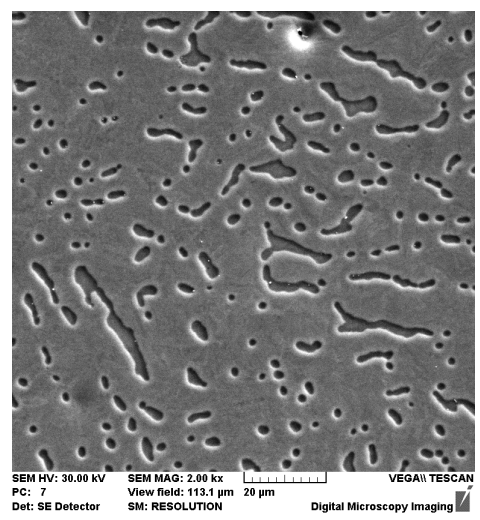

6

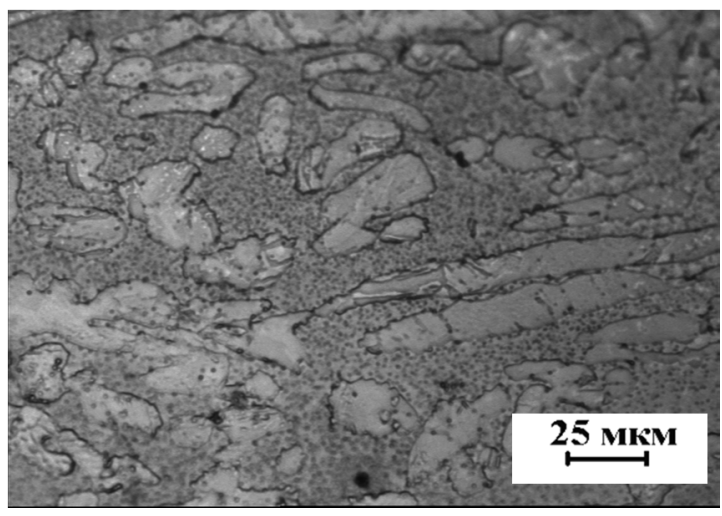

B

Рис. 1. Микроструктура закаленных от $1000^{\circ} \mathrm{C}$ сталей системы легирования 03Х14Н11К5М2ЮТ: $a$ - состав 4 ; $\sigma$ - состав 5 ; $в$ - состав 6

На рис. 1 a показана микроструктура закаленной от $1000{ }^{\circ} \mathrm{C}$ (в воду) однофазной аустенитной стали $03 \mathrm{X} 14 \mathrm{H} 11$ К $5 \mathrm{M} 2$ ЮТ состава 4 , где аустенитные зерна имеют форму многоугольников неправильной формы размером около 50 мкм, многие из них содержат двойники отжига. Двойники проявляются как полосы с параллельными краями и формируются вследствие образования дефектов упаковки атомов вдоль плотно упакованных плоскостей типа (111) при рекристаллизации и росте зерна. В закаленном состоянии сталь парамагнитна.

На рис. 1 б показана микроструктура закаленной от $1000{ }^{\circ} \mathrm{C}$ (в воду) стали состава 5 , которая была потравлена специально для выявления $\delta$-феррита в аустенитной матрице. Частицы $\delta$-феррита приобрели несколько приплюснутую форму в результате предварительной ковки. В магнитном отношении материал представляет собой слабый ферромагнетик, максимальная намагниченность $\mu_{0} M$ которого не превосходит 8 мТл в поле напряженностью $60 \kappa \mathrm{A} / \mathrm{M}$. 
Закаленная сталь состава 6 (рис. 1 в) состоит примерно из равного количества аустенита и $\delta$-феррита. По сравнению с составами 4 и 5 она имеет повышенный предел текучести за счет присутствия $\delta$-феррита, микротвердость которого составляет порядка $500 \mathrm{HV}$, в то время как микротвердость аустенита находится в пределах $200 \mathrm{HV}$. Аномально высокая твердость $\delta$-феррита (см. табл. 2) обусловлена наличием в нем равномерно распределенных дисперсных частиц округлой формы $\beta$-фазы на основе интерметаллида NiAl [12]. Двухфазная $\gamma+\delta$ структура обеспечила повышенную прочность уже в закаленном состоянии $\left(\sigma_{0,2} \sim 730 \mathrm{MПа;} \sigma_{\mathrm{B}} \sim 940 \mathrm{MПа)} \mathrm{при} \mathrm{сохранении} \mathrm{высокой} \mathrm{пластичности} \mathrm{(табл.} \mathrm{3).} \mathrm{Материал}\right.$ демонстрирует ферромагнитные свойства: максимальная намагниченность $\mu_{0} M$ в поле напряженностью $60 \mathrm{\kappa A} / \mathrm{M}$ достигает 0,6 Тл, а коэрцитивная сила $H_{C}$ составляет около 1,8 кА/м.

Заготовки стали состава 4 после закалки были протянуты без промежуточных отжигов с диаметра 8,0 мм до диаметра 1,46 мм, истинная деформация $\varepsilon$ при этом составила порядка 3,3. Заготовки составов 5 и 6 тянули до потери пластичности. Холодная пластическая деформация исследуемых сталей приводит к существенному упрочнению, обусловленному, во-первых, наклепом и усилением дефектности структуры твердого раствора вследствие скольжения и двойникования, а во-вторых, интенсивностью протекания $\gamma \rightarrow \alpha$ или $\gamma \rightarrow \varepsilon \rightarrow \alpha$ превращений, появлением в аустените высокодисперсных кристаллов мартенсита, способных «наследовать» дефекты аустенита.

Результаты магнитных измерений свидетельствуют, что интенсивность образования мартенсита деформации и связанного с ним TRIP-эффекта в исследованных сталях неодинаковы. На рис. 2 намагниченность в максимальном приложенном поле $\mu_{0} M$ образцов исследованных составов показана как функция величины достигнутой деформации, где $d_{0}-$ исходный диаметр проволоки, $d$ - текущий диаметр проволоки, отобранной по маршруту волочения. Видно, что в стали аустенитного класса 03Х14Н11К5М2ЮТ (состав 4) нарастание намагниченности происходит значительно менее интенсивно, чем в стали состава 5. Такая особенность деформационного поведения стали 4 обусловлена влиянием кобальта в количестве 5 вес. \%, снижающего энергию дефекта упаковки, от величины которой зависит прежде всего подвижность дислокаций [13]: чем ниже энергия дефекта упаковки, тем активнее происходит двойникование и (или) $\gamma \rightarrow \varepsilon$ превращение при деформации, а скольжение дислокаций, напротив, подавляется. В составе 4 активное образование $\varepsilon$-мартенсита за счет добавок 5 вес. \% кобальта приводит к постепенной реализации умеренного, без лавинообразной кинетики деформационного $\gamma \rightarrow \alpha$ превращения. В результате волочения на диаметр 1,46 мм $(\varepsilon=3,35)$ количество образованного $\alpha^{\prime}$-мартенсита деформации в структуре не превосходит 90 об. \%. Обнаруженный характер метастабильности этой стали определяет ее высокую пластичность и дает возможность проводить интенсивную пластическую деформацию с чрезвычайно высокими степенями обжатия без промежуточных отжигов.

Пониженное до 1,0 вес. \% содержание кобальта уменьшает область $\gamma \rightarrow \varepsilon$ превращения, усиливает интенсивность образования $\alpha^{\prime}$-мартенсита деформации. В результате этого в стали состава 5 наступает потеря пластичности на более ранних степенях обжатия (при $\varepsilon \sim 2,2)$. В интервале деформаций $1,0 \leq \varepsilon \leq 2,0$ отмечен резкий рост намагниченности в максимальном приложенном поле, который свидетельствует о весьма высокой продуктивности деформационного $\gamma \rightarrow \alpha$ превращения. При этом количество ферромагнитной фазы к концу маршрута волочения достигает 98 \% (мартенсит деформации и деформированный $\delta$-феррит). 


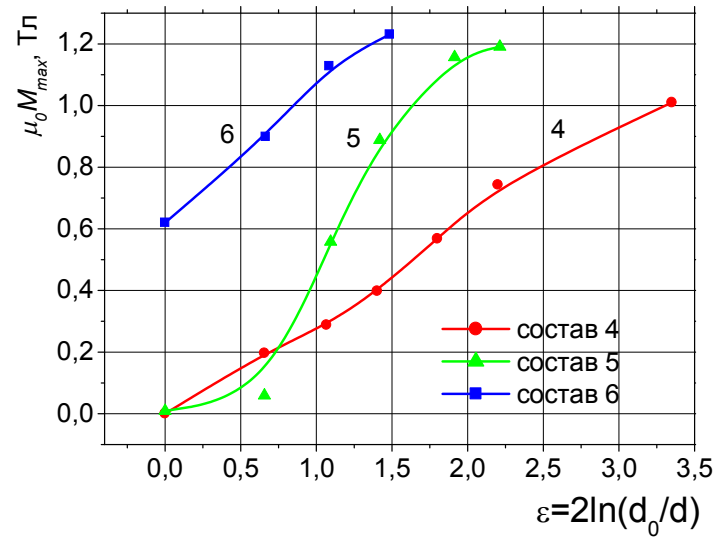

Рис. 2. Намагниченность в максимальном приложенном поле $\mu_{0} M$ образцов исследованных составов как функция величины достигнутой деформации по маршруту волочения: $\mu_{0}=4 \pi \cdot 10^{-7} \Gamma \mathrm{H} / \mathrm{M}-$ магнитная постоянная, $d_{0}-$ исходный диаметр проволоки, $d$ - текущий диаметр проволоки

В аустенитно-ферритной стали состава 6 -фферрит является фазой с высокой твердостью, создает препятствия для движения дислокаций и обеспечивает более высокий коэффициент деформационного упрочнения. В результате этого в стали состава 6 отмечена потеря пластичности при степени обжатия $\sim 1,4$. Однако аустенит в стали состава 6 также испытывает $\gamma \rightarrow \alpha$ превращение. Сравнение наклона деформационных зависимостей намагниченности в максимальном приложенном поле $\mu_{0} M$ (ع) показывает, что количество $\alpha^{\prime}$-мартенсита в процессе волочения стали 6 нарастает примерно с той же интенсивностью, что и при волочении заготовок состава 4. Этот факт подтверждает ключевую роль кобальта в контролировании интенсивности деформационных фазовых превращений в данной системе легирования: содержание кобальта в составах 4 и 6 одинаково и составляет 5,0 вес. \%.

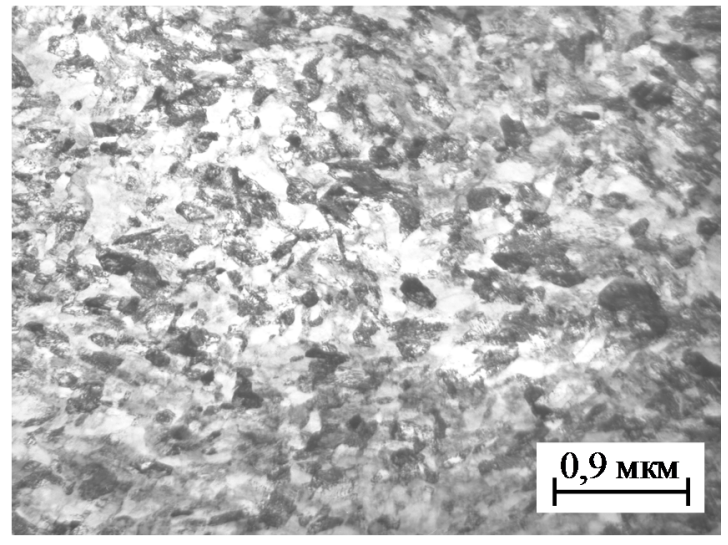

$a$

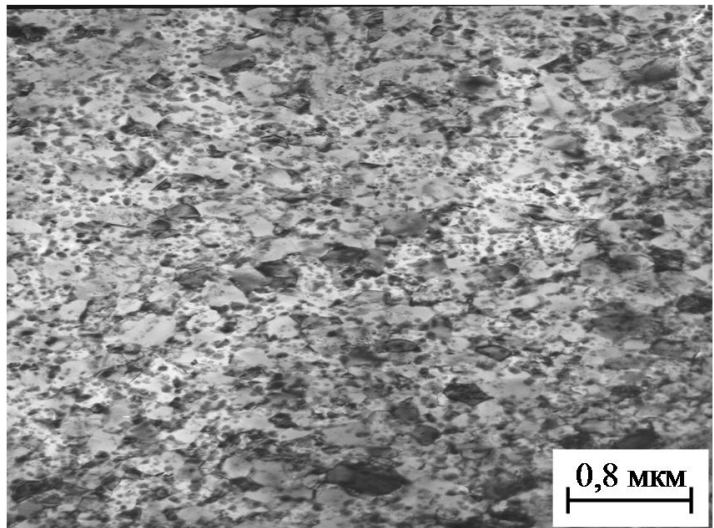

6

Рис. 3. Микроструктура стали состава 4: $a$ - после волочения на диаметр 1,46 мм $(\varepsilon=3,35) ; \sigma-$ после волочения на диаметр 1,46 мм $(\varepsilon=3,35)$ и старения при $500{ }^{\circ} \mathrm{C}$

На рис. 3 a показана микроструктура стали состава 4 после волочения на диаметр 1,46 мм $(\varepsilon=3,35)$, на которой выявляются фрагменты (блоки) различной степени травимости так называемого «бесструктурного» мартенсита, не имеющего игольчатого строения, характерного для преимущественно мартенситной структуры. Ранее проведенные электронномикроструктурные исследования на стали 03Х14Н11К5М2ЮТ после начальных этапов маршрута волочения показали появление многочисленных дефектов и двойников на фоне однородно распределенных дислокаций. Под действием интенсивной пластической дефор- 
мации с $e \geq 2,5$ формируется субмикрокристаллическая структура с размером зерна около 100 нм, а также более мелкие кристаллиты размером 20-50 нм, образовавшиеся при дроблении мартенситных пластин и двойников

В табл. 3 показано, как меняются механические характеристики исследованных материалов под действием холодной пластической деформации. Видно, что наиболее значительного деформационного упрочнения ( $\sigma_{\mathrm{B}}=1800 \mathrm{MПа)} \mathrm{удалось} \mathrm{достичь} \mathrm{при} \mathrm{волочении} \mathrm{аусте-}$ нитной стали с повышенным содержанием кобальта (состав 4), которая, как оказалось, обладает большим запасом пластичности и повышенной технологичностью даже после интенсивной пластической деформации $(\varepsilon=3,35)$. Волочение стали с пониженным содержанием кобальта до степени истинной деформации $\varepsilon>2$ признано нецелесообразным ввиду ограниченного ресурса пластичности.

Таблица 3 - Механические и магнитные свойства исследованных сталей системы легирования 03Х14Н11К5М2ЮТ после закалки, волочения и старения

\begin{tabular}{|c|c|c|c|c|c|c|c|}
\hline \multirow{2}{*}{$\begin{array}{c}\text { Химический } \\
\text { состав }\end{array}$} & \multirow{2}{*}{ Состояние } & \multirow{2}{*}{$\begin{array}{l}\sigma_{\mathrm{B}} \\
\mathrm{M \Pi а}\end{array}$} & \multirow{2}{*}{$\begin{array}{l}\sigma_{0.2} \\
\text { МПа }\end{array}$} & \multirow{2}{*}{$\begin{array}{l}\delta, \\
\%\end{array}$} & \multirow{2}{*}{$\begin{array}{l}\psi \\
\%\end{array}$} & \multicolumn{2}{|c|}{ Магнитные свойства } \\
\hline & & & & & & $\mu_{0} M_{\max }$, Тл & $H_{C}, \kappa \mathrm{A} / \mathrm{M}$ \\
\hline 4 & Закалка & 540 & 245 & 63 & 78 & $<0,001$ & 7,42 \\
\hline 4 & $\begin{array}{c}\text { Закалка }+ \text { волочение } \\
(\varepsilon=3,3)\end{array}$ & 1800 & 1650 & 14 & 43 & 1,06 & 4,33 \\
\hline 4 & $\begin{array}{c}\text { Закалка + волочение } \\
(\varepsilon=3,3)+\text { старение }\end{array}$ & 2500 & - & - & - & 0,92 & 13,76 \\
\hline 5 & Закалка & 580 & 340 & 53 & 76 & 0,008 & 3,55 \\
\hline 5 & $\begin{array}{c}\text { Закалка + волочение } \\
(\varepsilon=2,3)\end{array}$ & 1620 & 1500 & 5 & 35 & 1,19 & 2,52 \\
\hline 6 & Закалка & 940 & 730 & 25 & 51 & 0,60 & 1,77 \\
\hline 6 & $\begin{array}{c}\text { Закалка + волочение } \\
(\varepsilon=1,5)\end{array}$ & 1650 & 1550 & 8 & 47 & 1,21 & 5,85 \\
\hline
\end{tabular}

В ранее проведенных исследованиях было показано, что максимальное дисперсионное твердение в данной системе легирования обеспечивается изотермической выдержкой при $500{ }^{\circ} \mathrm{C}$ [14]. После деформации волочением образцы стали 4 были подвергнуты старению по режиму: $500{ }^{\circ} \mathrm{C}, 1$ час. Временное сопротивление при этом возрастает от 1800 МПа в холоднодеформированном состоянии до 2500 МПа (см. табл. 3). Оптическая металлография не позволяет выявить заметных структурных изменений при старении (см. рис. 3 б), но ранее проведенная электронная микроскопия после старения при $500{ }^{\circ} \mathrm{C}$ показала выделение высокодисперсных частиц $\beta$-фазы на основе интерметаллида (Fe, Ni)Al в мартенсите деформации. При этом в областях $\delta$-феррита отмечено подрастание ранее выделившихся частиц (Fe, $\mathrm{Ni}) \mathrm{Al}$ до величины $\sim 40$ нм. 


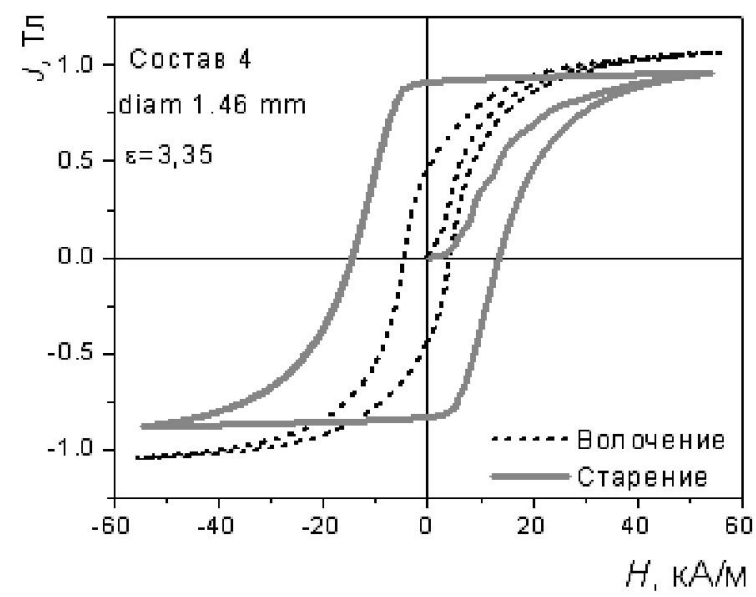

Рис. 4. Петли магнитного гистерезиса исследованной стали (состав 4) после волочения на диаметр 1,46 мм $(\varepsilon=3,35)$ и старения при $500{ }^{\circ} \mathrm{C}(1$ час $)$

Появление дисперсных наноразмерных частиц в ферромагнитной $(\alpha+\delta)$-матрице объясняет резкий рост коэрцитивной силы деформированной стали под действием старения (см. табл. 3). На рис. 4 показаны предельные петли магнитного гистерезиса исследованной стали состава 4, зарегистрированные после волочения на диаметр 1,46 мм (пунктирная линия) и после старения при $500{ }^{\circ} \mathrm{C}$ (сплошная линия). Увеличение коэрцитивной силы в четыре раза является наиболее заметным, но не единственным изменением в магнитном поведении материала в результате прошедшего дисперсионного упрочнения. Петля магнитного гистерезиса деформированного материала имеет характерную «веретенообразную» форму, что указывает на преобладание процессов вращения векторов намагничивания над процессами смещения и является типичным для материалов с высоким уровнем внутренних напряжений. В результате выдержки при температуре $500{ }^{\circ} \mathrm{C}$ в течение 1 часа петля приобрела более прямоугольные очертания. Наконец, некоторое снижение достигнутой максимальной намагниченности согласуется с данными о появлении в структуре небольшого количества ревертированного аустенита, что ранее сообщалось [14] на основании результатов магнитного и рентгеноструктурного анализа после старения в интервале температур $500-700{ }^{\circ} \mathrm{C}$.

\section{4. Заключение}

Вновь разработанные стали системы легирования Fe-Cr-Ni-Co-Al-Ti обладают большим запасом технологической пластичности и выдерживают деформацию волочением с высокими степенями обжатия без промежуточных отжигов. В дуплексной аустенитоферритной стали потеря пластичности наступила при $\varepsilon=1,5$, в стали с пониженным содержанием кобальта - при $\varepsilon=2,3$. Аустенитная сталь с повышенным до 5,0 вес. \% содержанием кобальта показала наилучшую пластичность: эксперимент по волочению был остановлен по достижению деформации $\varepsilon=3,3$ при сохранении технологической пластичности материала.

Обоснована необходимость легирования кобальтом для повышения технологической пластичности и создания высокопрочных коррозионностойких сталей, потенциально способных выдерживать интенсивную пластическую деформацию с высокими степенями обжатия без промежуточных отжигов. Полученная в работе чрезвычайно высокая пластичность при холодной деформации волочением достигается за счет совместного действия микродвойникования и мартенсиных превращений с оптимальной интенсивностью.

Дисперсионное твердение при $500{ }^{\circ} \mathrm{C}$ (1 час) после волочения увеличивает прочность разработанного материала до $\sigma_{0.2}=2500 \mathrm{MПа,} \mathrm{что} \mathrm{позволяет} \mathrm{значительно} \mathrm{уменьшить} \mathrm{попе-}$ речное сечение стержневого медицинского инструмента по сравнению с обычными аусте- 
нитными сталями при сохранении того же запаса прочности и, как следствие, сделать хирургическое вмешательство менее травмирующим и болезненным для пациента.

Метод магнитного анализа позволяет осуществлять мониторинг структурных и фазовых изменений в разработанных сталях при деформационно-термической обработке: после отжига на твердый раствор, в процессе холодной деформации и по окончании дисперсионного твердения. Деформационная зависимость намагниченности в максимальном приложенном поле отражает интенсивность $\gamma \rightarrow \alpha$ превращения в процессе волочения проволоки. Старение при $500{ }^{\circ} \mathrm{C}$ (1 час) приводит к многократному росту коэрцитивной силы за счет выделения интерметаллидных частиц $\beta$-фазы в ферромагнитной матрице, что указывает на перспективность неразрушающего контроля прочностных характеристик материала на заключительном этапе технологического процесса.

\section{Литература}

1. Коррозионностойкие, жаростойкие и высокопрочные стали и сплавы: справочник / А. П. Шлямнев, Т. В. Свистунова, О. Б. Лапшина и др.; Центр. науч.-исслед. ин-т черной металлургии им. И. П. Бардина, Некоммерч. партнерство "Спецметаллы". - М. : Интермет Инжиниринг, 2000. - 232 с.

2. Горынин И. В., Малышевский В. А., Рыбин В. В. Высокопрочные свариваемые корпусные стали для подводного кораблестроения: вчера, сегодня, завтра. В кн.: Роль российской науки в создании отечественного подводного флота / под общ. ред. А. А. Саркисова; РАН - М. : Наука, 2008. - С. 281-288.

3. Gavriljuk V. G., Berns H. High Nitrogen Steels. - Berlin : Springer Verlag, 1999. - 378 p.

4. Структура и коррозия металлов и сплавов: атлас: справочник / И. Я. Сокол и др.; под ред. Е. А. Ульянина. - М. : Металлургия, 1989. - 399 с.

5. Davison M., Redmond J. D. Practical guide to using duplex stainless steels // Materials Performance. - 1990. - Vol. 29. - P. 57-62.

6. Marshall P. Austenitic Stainless Steels. Microstructure and Mechanical Properties. London : Elsevier, 1984. ISBN: 0-85334-277-6.

7. Berns H., Gavriljuk V. G., Riedner S. High interstitial stainless austenitic steels. - Berlin : Springer Verlag, 2013. - 167 p.

8. $\quad$ Sinha K. Ferrous Physical Metallurgy. - Berlin : Butterworths, 1989. - 335 p.

9. Desestret A., Charles J. The duplex stainless steels. In: Stainless steels. P. Lacombe // Eds B. Baroux, G. Beranger. - Les Ulis, France : Les editions de physique, 1993. - P. 612-658.

10. Бернштейн М. Л. Структура деформированных металлов. - М. : Металлургия, 1977. $-431 \mathrm{c}$.

11. Филиппов М. А., Литвинов В. С., Немировский Ю. Р. Стали с метастабильным аустенитом. - М. : Металлургия, 1988. - 255 с.

12. Коррозионная стойкость высокопрочных алюминийсодержащих сталей для мединструмента / Л. А. Мальцева, Н. Н. Озерец, Н. Г. Россина, Т. В. Мальцева, В. А. Шарапова // Материаловедение. - 2009. - № 6. - С. 11-16.

13. Гольдштейн М. И., Литвинов В. С., Бронфин Б. М. Металлофизика высокопрочных сплавов: Учеб. пособие для вузов. - М. : Металлургия, 1986. - 312 с.

14. Мальцева Л. А. Структура и прочностные свойства коррозионно-стойкой аустенитноферритной стали медицинского назначения после термопластической деформации // Деформация и разрушение материалов. - 2010. - № 1. - С. 1-8. 